\title{
Cognitive Function and Blood Pressure Examination in Padang Bulan Selayang II Subdistrict
}

\author{
Irina Kemala Nasution", Aldy Safruddin Rambe, Fasihah Irfani Fitri, \\ Iswandi Erwin \\ Department of Neurology, Faculty of Medicine, Universitas Sumatera Utara
}

\begin{abstract}
Hypertension is one of the main health problems in Indonesia, which if not controlled will result in health, psychological, social and economic burdens. A common clinical consequence of hypertension is impaired cognitive function, namely dementia and senility, which can be examined through the Indonesian version of the Montreal Cognitive Assessment (MoCA-Ina). The service program which is carried out by the Faculty of Medicine, Universitas Sumatera Utara (FK USU) is an examination of cognitive function and blood pressure in Padang Bulan Selayang II region. Examinations are carried out in accordance with the 2017 World Alzheimer Month and are followed by lay seminars on dementia, brain gym exercises (gerak latih otak/GLO) as well as brain teasers. The activity involved 26 participants from integrated development post (pos pembinaan terpadu / Posbindu) with a mean systolic blood pressure (TDS) $131.54 \pm 18.70 \mathrm{mmHg}$, mean diastolic blood pressure (TDD) $83.85 \pm$ $8.98 \mathrm{mmHg}$, mean mean arterial pressure 99, $69 \pm 9.47 \mathrm{mmHg}$ and a mean MoCA-Ina score of $22 \pm 5.03$. Blood pressure monitoring, education of community awareness and cognitive stimulation at regular intervals are expected to prevent and reduce the incidence of hypertension, dementia and senility.
\end{abstract}

Keywords: Hypertension, Dementia, Cognitive Function

Abstrak. Hipertensi merupakan salah satu masalah utama kesehatan di Indonesia yang apabila tidak terkontrol akan mengakibatkan beban implikasi baik kesehatan, psikologi, sosial maupun ekonomi. Konsekuensi klinis yang umum terjadi pada hipertensi ialah gangguan fungsi kognitif yakni demensia dan kepikunan yang dapat diperiksa melalui perangkat Montreal Cognitive Assessment versi Indonesia (MoCA-Ina). Program pengabdian yang dilaksanakan oleh Fakultas Kedokteran Universitas Sumatera Utara (FK USU) ialah pemeriksaan fungsi kognitif dan tekanan darah yang dilakukan di Kelurahan Padang Bulan Selayang II. Pemeriksaan dilakukan dalam rangka menyambut Bulan Alzheimer Sedunia 2017 dan diikuti dengan seminar

*Corresponding author at: J1. DR. Mansyur No.5, Padang Bulan, Medan - Indonesia

E-mail address: wandierwin@yahoo.com 
awam mengenai demensia, senam gerak latih otak (GLO) juga permainan asah otak. Kegiatan melibatkan 26 peserta pos pembinaan terpadu (Posbindu) dengan hasil rerata tekanan darah sistolik (TDS) 131,54 $\pm 18,70 \mathrm{mmHg}$, rerata tekanan darah diastolik $(T D D)$ 83,85 $\pm 8,98 \mathrm{mmHg}$, rerata mean arterial pressure 99,69 \pm 9,47 mmHg dan rerata skor MoCA-Ina $22 \pm$ 5,03. Pemantauan tekanan darah, edukasi kepedulian masyarakat dan stimulasi kognitif secara berkala diharapkan dapat mencegah dan menurunkan angka kejadian hipertensi, demensia dan kepikunan.

Kata Kunci: Hipertensi, Demensia, Fungsi Kognitif

Received 28 August 2017 | Revised 5 February 2019| Accepted 29 March 2019

\section{Introduction}

Hypertension or high blood pressure is one of the important health problems in Indonesia. Based on the basic health data (Riskesdas) on 2013, hypertension is found in $25.8 \%$ of the population and contiributes $9.5 \%$ of non-communicable diseases (NCD) of the population aged $\geq 15$ years with a total of 722,329 people, where blood pressure that is not routinely and adequately controlled can cause clinical consequences in the form of organ disorders such as risk of heart disease, stroke, damage to kidney function (hypertensive nephropathy), eye retinal damage (hypertensive retinopathy) to symptoms of dementia (senility) and Alzheimer's disease [1,2]. A survey of hypertension and blood pressure measurements conducted by the Indonesian Society of Hypertension (Ina-SH) on the knowledge of health care supervisors, as much as $25.4-29,7 \%$ of these respondents lack the understanding about hypertension and correct blood pressure measurements [3], indicating the need of information proliferation and transfer about hypertension and its consequences on society.

A known consequence of prolonged uncontrolled hypertension is dementia (senility) and Alzheimer's disease, which is present in $60-80 \%$ of the population and is one of the most frequently found neurodegenerative diseases. There are several risk factors that are either unmodifiable (age, sex, genetic factors) or modifiable (hypertension, diet / food patterns and unhealthy lifestyles) [4]. Prevention is the primary method to decrease the incidence of dementia which currently is still increasing.

One recommended screening method that can be used for patients with subjective complaints of dementia is the usage of dementia screening tools [5]. This is due to the condition of transition between a healthy brain to dementia known as mild cognitive impairment. (MCI), or vascular cognitive impairment (VCI) if vascular risk factors are found. The most commonly used tools includes themini mental state examination 
(MMSE) and the MoCA-Ina (The Indonesian version of the Montreal Cognitive Assessment). As one of the device models adapted from foreign languages and cultures, MoCA-Ina is a tool that has been validated and tested by [6] by comparing it to the original MoCA [7] through the transcultural 7-step validation method recommended by World Health Organization (WHO). In addition, MoCA as acognitive assesment tool have advantages on certain domains such as executive functions as well as higher sensitivity compared to MMSE (90\% vs. 18\%).

Senility can be prevented as early as possible on those who might have complaintsby using the appropriate program. Brain gym exercises (gerak latih otak / GLO) is a gymnastic activity developed by [8] which includes simultaneous physical stimulation and cognitive stimulation training [9]. The GLO program is quite easy to do by following the movements exemplified by the instructor as well as playing 30 minutes of gymnastic video, which is practicable anywhere. The use of public facilities and group stimulation is one option in implementing GLO. Integrated developnment posts (Posbindu) is a form of public and policy maker/stakeholders participation in carrying out early detection and monitoring of risks in non-communicable diseases (NCD) which are carried out in an integrated and routine manner within a certain period (periodical) [10]. Utilization of subdistrict Posbindu kelurahan is one of the efforts in implementing prevention programs and early detection of cases of hypertension and dementia, with a goal of early treatment before falling into more severe conditions.

\section{Method}

The public service method at Posbindu of Padang Bulan Selayang II is carried out on 26 subjects, who are village residents and is set at a time in accordance with the World Alzheimer's Month which falls in September. The program consists of blood pressure checks, cognitive function examinations, lay seminars on dementia (senility), GLO exercises and brain games. The examination involved lecturers and practitioners (neurology specialists), neurology residents, and medical students of Faculty of Medicine, Universitas Sumatera Utara (FK USU) and volunteers from the Alzheimer's Foundation of Indonesia (ALZI) Medan Region. Examinations and activities are allocated according to the level of examiner's competence, including blood pressure checks by medical students, while cognitive function tests are carried out by resident doctors who have passed the neurobehavior examination level competence (stage III competency level) (Figure 1). 


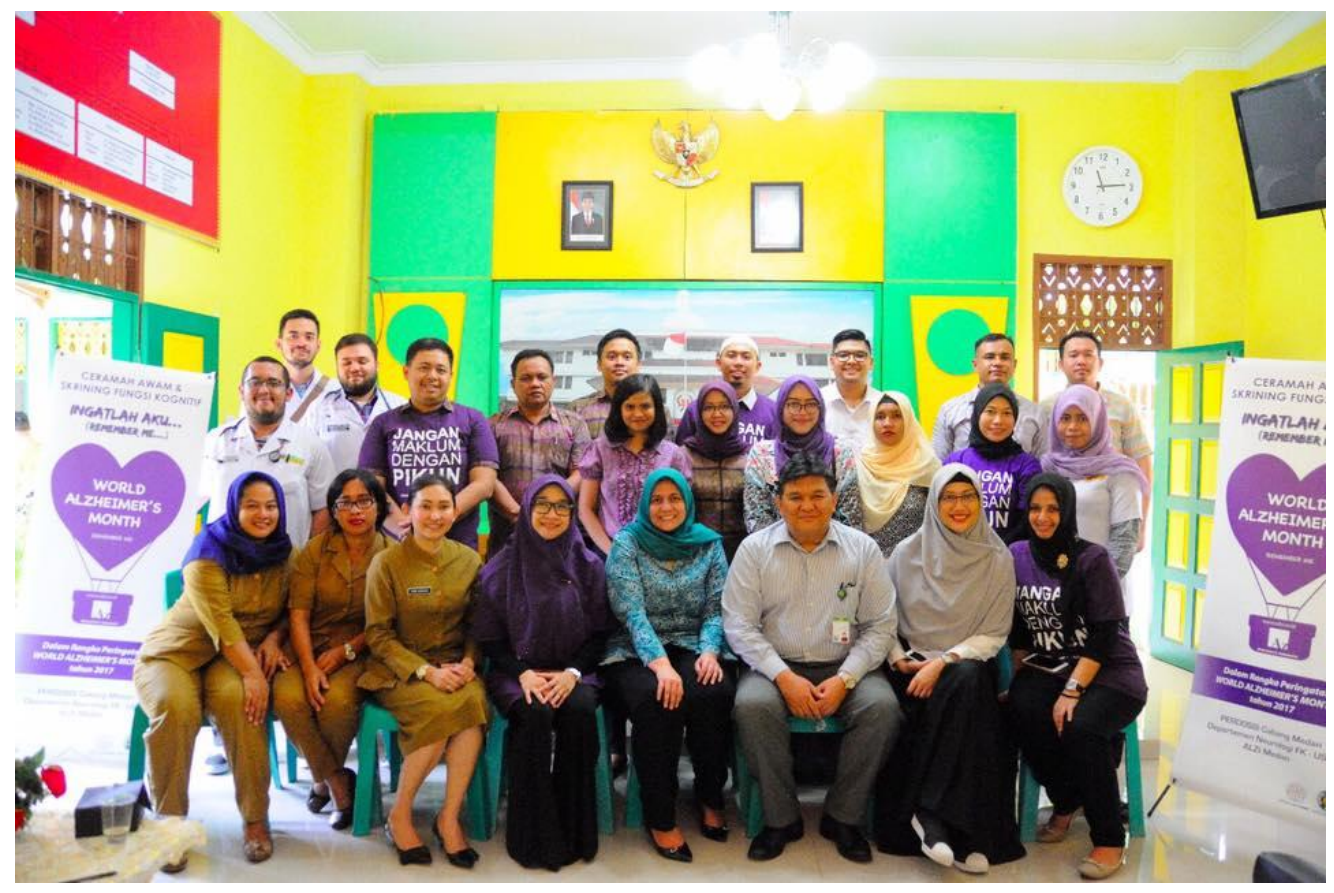

Figure 1. Team for Blood Pressure Examination and Cognitive Function of FK USU-Alzi Korwil Medan-Posbindu Padang Selayang II Subdistrict.

Before the blood pressure examination, the patient was interviewed about age, level of education, complaints and previous illnesses. Blood pressure measurements are carried out in accordance with the standard procedure of blood pressure using a mercury manometer that have been previously applied by The National Health and Nutrition Examination Survey (NHANES), in which patients were asked to sit down to rest for 5 minutes, followed by maximum cuff inflation and sistolic / diastolic pressure are measured 3 seperate times and the mean values are taken. Quick cognitive function assesement were done using Montreal Cognitive Assessment - Indonesian version (MoCA-Ina) which has been validated previously [11].

After conducting blood pressure checks and cognitive functions, the participants then attended a lay seminar which was guided by one of the presenters who were experts in the field of dementia and hypertension (neurology specialists). The lay seminar continued with a question and answer session, so that participants who still lacked understanding or wanted to understand more about the topic may receive the information they seek. Afterwards, the participants were invited to do GLO gymnastics with therecommended sequences and movements. The exercise is led by an instructor and assisted by screens, projectors and a video showing movement that can be easily replicated by participants. After completing GLO exercises, participants were invited to join brain games that 
helped participants understand normal memory processes and senility, while training participants' memory and cognitive functions ( Figure 2 ).

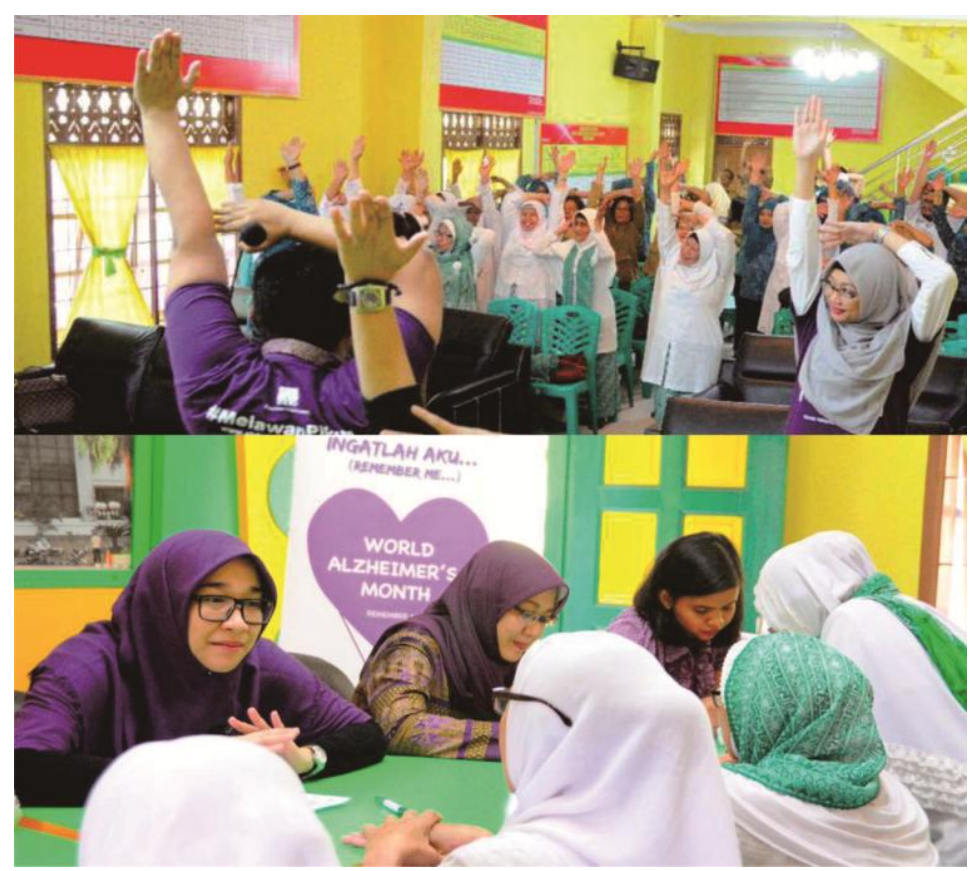

Figure 2. Brain Gym Exercises (GLO), Brain Stimulation and Cognitive Function

Examination

\section{Result and Discussion}

There were 26 subjects with characteristic variables, results of blood pressure examination and cognitive function (using MoCA-Ina tools) listed in Table 1.

Table 1. Characteristics, Mean Blood Pressure and Cognitive Functions of Participants

\begin{tabular}{cc}
\hline Characteristic variable $(\mathrm{n}=26)$ & Average \\
\hline Age & $56.35 \pm 10,70$ years \\
Systolic pressure $(\mathrm{mmHg})$ & $131,54 \pm 18.70$ \\
Diastolic pressure $(\mathrm{mmHg})$ & $83,85 \pm 8,98$ \\
Mean Arterial Pressure & $99.69 \pm 9.47$ \\
MoCA -Ina score & $22 \pm 5,03$ \\
\hline
\end{tabular}

Blood pressure examination showed the average systolic blood pressure of $131.54 \pm$ $18.70 \mathrm{mmHg}$, while the average diastolic blood pressure was $83.85 \pm 8.98 \mathrm{mmHg}$. A review from the Joint National Committee (JNC) 8 consisting of panelists in the field of hypertension suggested that in the age group of 30 to 59 years, it is recommended to control diastolic blood pressure below $90 \mathrm{mmHg}$, whereas in the group age above 60 years and above it is recommended to have a blood pressure below 150/90 $\mathrm{mmHg}$. Based on the criteria above, the mean blood pressure and mean arterial pressure of the 
participants of the Posbindu activity in Padang Subdistrict II Month is still within the recommended limits [12].

In accordance with the principle of Hi-Brainfit, physical stimulation and brain stimulation are expected to be carried out simultaneously by programs to train and develop the cognitive functions of the brain as well as reduce the risk of dementia and other degenerative diseases. This is supported by the pre- and post-test studies conducted by Setyawan [13] where there are differences in the form of improving cognitive function of the elderly before and after brain gym and kinesiology education. Stimulation in the form of GLO gymnastics is also expected to reduce blood pressure in the population according to Mayuni's [14] study, which revealed that exercise in elderly groups can reduce systolic blood pressure by $8.75 \mathrm{mmHg}$, diastolic blood pressure by $11.25 \mathrm{mmHg}$ and mean arterial pressure amounting to $10.42 \mathrm{mmHg}$.

The MoCA-Ina score shows the average is below the expected score (cut-off score of MoCA 24) [15]. In accordance with the research of Sjahrir et al [16] on the population in the city of Medan, it is clear that the quartile below the standard deviation will be evident in the elderly population who are generally the target subject in this study. Between the variables of hypertension and cognitive function, in general both of them have a close correlation as described by Alam's research [17] so that further research is needed to cover both factors with a more adequate number of subjects.

\section{Conclusion}

The blood pressure of the subjects fromthe Posbindu of Padang Bulan Selayang II is still within the recommended limits, but the cognitive function score is below the overall MoCA-Ina score in general $(<24)$. Coaching activities such as counseling, lay seminars, GLO exercises and continuous brain stimulation activities are expected to improve cognitive function.

\section{References}

[1] Badan Penelitian dan Pengembangan Kesehatan, Kementrian Kesehatan RI. 2013. Riset Kesehatan Dasar tahun 2013. Jakarta: 91-93.

[2] Pusat Data dan Informasi (Pusdatin) Kementrian Kesehatan RI. 2014. Info Datin Hipertensi (17 Mei-Hari Hipertensi Sedunia). Jakarta: 1-8.

[3] Rohman, M.S., Hersunarti, N., Soenarta, A.A., Suhardjono, Mayza, A., Lukito, A.A. 2011. Pemahaman Dokter Indonesia Mengenai Hipertensi dan Permasalahan yang Dihadapi pada Praktik Sehari-hari. Maj Kedokt Indon; 61(2): 51-58. 
[4] Herwati dan Sartika, W. 2013. Terkontrolnya Tekanan Darah Penderita Hipertensi Berdasarkan Pola Diet dan Kebiasaan Olahraga di Padang tahun 2011. Jurnal Kesehatan Masyarakat; 8(1): 8-15.

[5] Dikot, Y., Kusumoputro, S., Djokosetio, L., Samino, Nasrun, M.W., Nugroho, W. 2013. Konsensus Nasional Pengenalan dan Penatalaksanaan Demensia Alzheimer dan Demensia Lainnya. Asosiasi Alzheimer Indonesia. Jakarta.

[6] Husein, N., Lumempouw, S., Ramli, Y., Herqutanto. 2010. Uji Validitas dan Reliabilitas Montreal Cognitive Assessment versi Indonesia (MoCA-Ina) untuk Skrining Gangguan Fungsi Kognitif. Neurona 27(4):1-13.

[7] Nasreddine, Z.S., Phillips, N.A., Bédirian, V., Charbonneau, S., Whitehead, V., Collin, I., Cummings, J.L. and Chertkow, H., 2008. The MoCA: a better MMSE. The Carlat Psychiatry Report, 6(5), pp.1-5.

[8] Djokosetio, L.S., and Kusumoputro, S. 2003. Memori anda setelah usia 50. Jakarta: Penerbit Universitas Indonesia; p.1-95

[9] Sidiarto LD, Kusumoputro S, Samino, Munir R, and Nugroho W. 2003. The Efficacy of Specific Patterns of Movements and Brain Exercises on the Cognitive Performance of Healthy Senior Citizen in Jakarta. Med J Indones; 12: 155-61.

[10] Sudharma, N.I., Kusumaratna, R.K., and Meiyanti. 2016. Factors Influnce the Utilization of Community Participation. OIDA International Journal of Sustainable Development; 9(3): 77-89.

[11] Lin, M.P., Ovbiagele, B., Marcovic, D., and Towfighi, A. 2015. Systolic Blood Pressure and Mortality After Stroke: Too Low, No Go?. Stroke; 46: 1307-1313.

[12] James, P. A., Suzanne, O.M.D., Barry, L.C., William, C.C., Cheryl, D.H., Joel, H., et al.,2013. 2014 Evidence-Based Guideline for the Management of High Blood Pressure in Adults Report From the Panel Members Appointed to the Eighth Joint National Committee (JNC 8). JAMA (Journal of American Medical Association).

[13] Mayuni, I.G.A.O. 2013. Senam Lansia Menurunkan Tekanan Darah Lansia. Populasi: 1-5.

[14] Setyawan, E. 2015. Pengaruh Senam Lansia Dengan Brain Gym Terhadap Peningkatan Kognitif Pada Lansia (Skripsi Sarjana, Universitas Muhammadiyah Surakarta).

[15] Ong, P.A., Rambe, A.S., Widjojo, F.S., Laksmidewi, A.A.A.P. 2015. Panduan Praktik Klinik Diagnosis dan Penatalaksanaan Demensia. Jakarta: Perhimpunan Dokter Spesialis Saraf Indonesia.

[16] Sjahrir, H., Ritarwan, K, Tarigan, S., Rambe, A.S., Lubis, I.D., Bhakti, I. The mini mental state examination in healthy individuals in Medan Indonesia by age and education level. Neurol J Southeast Asia. 2001; 6: 19-22.

[17] Alam, R.P. 2015. Hubungan Antara Hipertensi dengan Fungsi Kognitif di Wilayah Kerja Posyandu Lansia Kecamatan Medan Amplas Tahun 2015. (Karya Tulis Ilmiah, Universitas Sumatera Utara). 